Original Research Paper

\title{
An Ultrastructural Study of Endoplasmic Reticulum of Mammary Secretory Cells in Rabbits During Lactation and Regression Stages
}

\author{
Svatoslav Hluchy and Robert Toman \\ Faculty of Agrobiology and Food Resources, Slovak University of Agriculture, 94976 Nitra, Tr. A. Hlinku 2, Slovakia
}

\author{
Article history \\ Received: 19-10-2014 \\ Revised: 22-11-2014 \\ Accepted: 27-11-2014 \\ Corresponding Author: \\ Svatoslav Hluchy \\ Faculty of Agrobiology and \\ Food Resources, Slovak \\ University of Agriculture, \\ 94976 Nitra, Tr. A. Hlinku \\ 2, Slovakia \\ Email: svatoslav.hluchy@uniag.sk
}

\begin{abstract}
The objective of the research was to study the changes of the Endoplasmic Reticulum (ER) in mammary epithelial cells of rabbits during lactation and regression stages. Our results using conventional transmission electron microscopy has shown that ER is changed during the various mammary gland development stages. We found that the average relative volume of ER achieves $17.7 \pm 2.464 \%$ of cytoplasm volume in the stage of lactation. During regression ER relative volume decreased to $1.274 \%$ of the cytoplasm. This difference compared to lactation is statistically significant $(\mathrm{p}<0.01)$. Relative surface of ER during lactation reaches $5,630 \pm 1,033 \mu \mathrm{m}^{2} / \mu \mathrm{m}^{3}$ of cytoplasm. We found a decrease of relative surface of ER to $0.192 \pm 0.069 \mu \mathrm{m}^{2} / \mu \mathrm{m}^{3}$ of cytoplasm during regression stage. The average size of ER cisternae and tubules reach $0,0953 \pm 0,012 \mu \mathrm{m}$ at lactation stage. During a stage of regression the average size of ER cisternae and tubules is $0.171 \pm 0.154 \mu \mathrm{m}$. This difference compared to lactation is not statistically significant.
\end{abstract}

Keywords: Electron Microscopy, Mammary Glands, Secretory Epithelial Cells, Endoplasmic Reticulum

\section{Introduction}

The endoplasmic reticulum is a permanent part of the cytoplasm of secretory epithelial cells of lactating mammary glands. It exists in two forms, both granular and agranular (smooth) endoplasmic reticulum. The Endoplasmic Reticulum (ER) has a crucial role in cellular metabolism (Invernizzi et al., 2012), intracellular distribution of reticuloplasmins and soluble proteins (Schinko et al., 1990; Sordillo and Nickerson, 1988). Endoplasmic reticulum was as efficient as Golgi apparatus in sequestration and accumulation of $\mathrm{Ca}^{2+}$ (Ghosal et al., 1994). Qu et al. (2012) stated that ER and mitochondria are an indicator of lactogenic activity of alveolar secretory cells.

The aim of this study was to describe changes of Endoplasmic Reticulum (ER) in epithelial secretory cells of lactating and involuting mammary glands in rabbits.

\section{Materials and Methods}

In this study samples of mammary glands of 10 rabbits were used. Depending on the stage of the physiological activity of the mammary glands rabbits were divided into two groups: Lactation and the regression stage. All animals were kept in standard conditions at Research Institute of Livestock Production in Nitra. Samples for electronoptical examination were collected for each of the three mammary glands (thoracic, abdominal and pubic) the right half of the body of rabbits immediately after killing the animal. A sample size of 1 to $1.5 \mathrm{~mm}^{3}$ were collected from glandular parenchyma and processed according to the methodology prepared by the (Mráz and Polónyi, 1988). Electronograms were made by electron microscope JEOL 100MX on the Elektronen Platte EU 2 ORWO at the Department of Reproduction (Research Institute of Livestock Production). We used a 7200-fold magnification, in some cases 3600, 10000 and 14000fold. For quantitative assessment methodology was used microscopic system Nikon Eclipse E 600 and camera Pixelink (PL-A642) in connection with software for image analyse Lucia 4.8. Basal statistical indicators and correlations were calculated from obtained data using Statgraphics statistical software. Basic variationalstatistical characteristics and the observed differences by ANOVA, F-test and Scheffe test were tested.

\section{Results}

Endoplasmic reticulum consists of gently flattened cisternae, tubules and vesicles arranged in parallel one 
above the other in the number 4-7 in rabbit's epithelial secretory cells of mammary glands during lactation stage. In some cases, the cisternae concentrically curving, while still being of a parallel arrangement. Cisternae arranged in parallel are in most cases close to the nucleus and may be above it and also on its sides. Shorter cisternae, tubules and vesicles are irregularly distributed throughout the cytoplasm between organelles of the cell, not excluding apical area (Fig. 1). The ribosomes are located on the membrane's surface and also in the cytoplasm, either free or connected together into rosettes and spirals (polysomes). Because of their size and amount was not possible to quantitatively evaluate the relative volume, surface, size and abundance.

Disintegration and changes of granular endoplasmic reticulum comes to after the end of lactation. Cisternae are expanding, but this expansion compared to the cisternae thickness in lactation stage is not statistically significant. Long cisternae are broken down into shorter, losing their parallel arrangement. Ribosomes were released from the membrane surface of granular endoplasmic reticulum after the cessation of protein synthesis, so in some cases cisternae with smooth membranes and some even thinner membranes occurring ribosomes were observed (Fig. 2). The density of free ribosomes in the cytoplasm is higher compared to the period of lactation.

The average relative volume of endoplasmic reticulum reach $17.7 \pm 2.464 \%$ of cytoplasm during stage of lactation. The relative volume of ER correlates with the relative volumes of other structures of cytoplasm. Medium strong positive correlations were found only with the relative volume of mitochondria and weak correlations with the relative volume of fat droplets were found. Strong negative correlations with the relative volume of other structures (Golgi complex, secretory vesicles, granules within the secretory vesicles, empty vacuoles, lysosomes, multivesicular bodies and agranular endoplasmic reticulum) were calculated.

The relative volume of ER in rabbits during regression stage decreased up to $1.274 \%$ of the cytoplasm, which in comparison with the relative volume during lactation is statistically highly significant difference ( $\mathrm{P} \angle 0.01)$. The relative volume of ER during this period negative correlates with the relative volume of smooth membranes and also the relative volume of fat droplets. Positive correlation with other structures of cytoplasm was found. The above correlation relationships are consistent with our subjective observations.

The average relative surface of ER reach $5,630 \pm 1,033 \mu \mathrm{m}^{2} / \mu \mathrm{m}^{3}$ of cytoplasm at stage of lactation. Endoplasmic reticulum relative surface after lactation

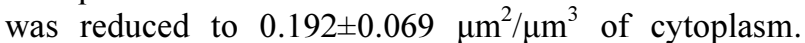
Relative surface reduction compared with period of lactation data is statistically significant $(\mathrm{P} \angle 0,50)$. ER relative surface negatively correlated with the surface of smooth membrane cisternae surface, surface of fat droplets and also with the surface of lysosomes.

The average size of ER cisternae and tubules reach $0.0953 \pm 0.012 \mu \mathrm{m}$ at lactation stage. Average size negatively correlates with the average thickness of mitochondria and multivesicular bodies. During a stage of regression the average size of ER cisternae and tubules is $0.171 \pm 0.154 \mu \mathrm{m}$. This difference compared to lactation is not statistically significant.

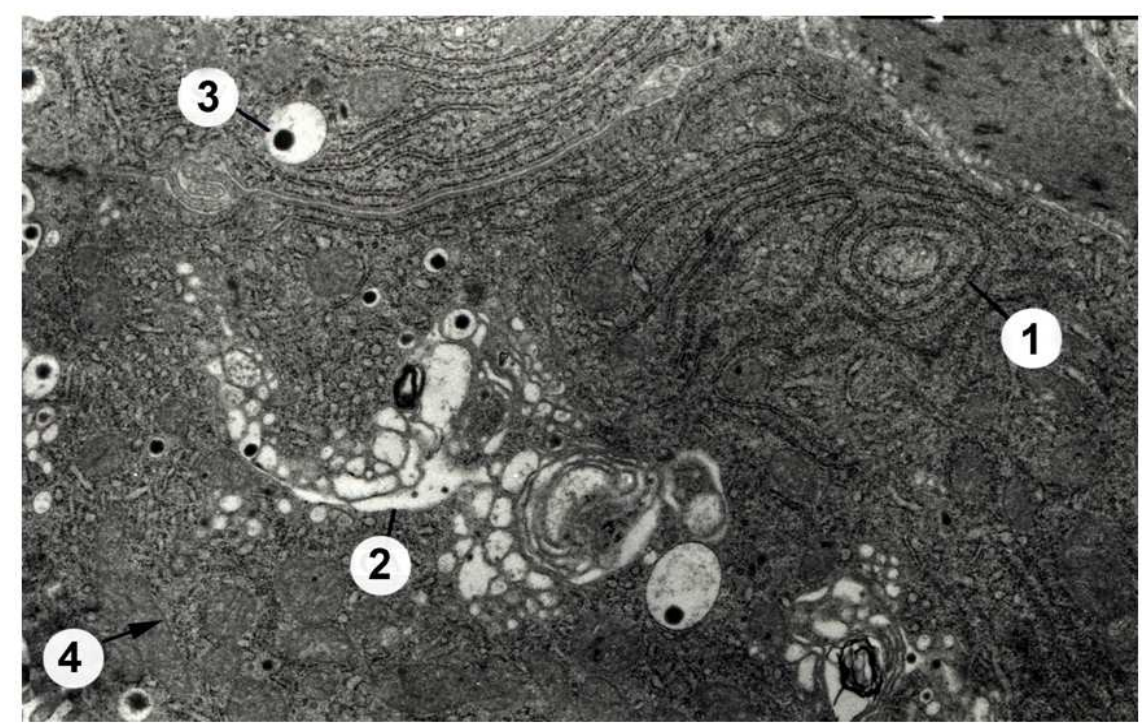

Fig. 1. Secretory epithelial cell of mammary gland of rabbit during lactation 1-endoplasmic reticulum cisternae with ribosomes, 2Golgi apparatus, 3-secretory vesicle with protein granule, 4-mitochondria 


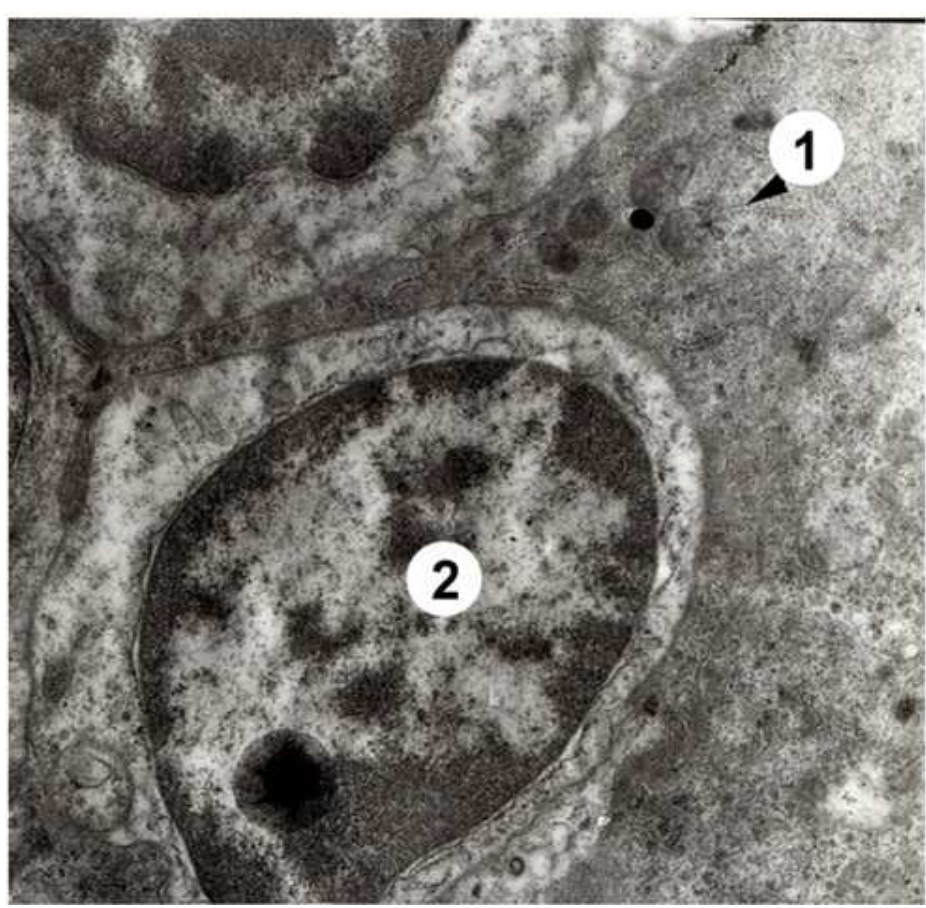

Fig. 2. Secretory epithelial cell of mammary gland of rabbit during regression stage 1-disintegration of endoplasmic reticulum cisternae, 2-nucleus

\section{Discussion}

Our observations of shape, arrangement and location of Endoplasmic Reticulum (ER) in rabbits epithelial secretory cells do not differ from the observations of other authors for instance (Helminen and Ericsson, 1968) in rat, Reid and Chandler (1973) in mice and (Uhrín and Kliment, 1982) in cattle and (Jimenez et al., 1984) in bat. If we compare our data on the relative volume of ER $17.718 \%$ in rabbits with those of other authors, we see that (Uhrín and Kliment, 1982) found 10.37 to $13.96 \%$. in cows. In contrast (Pulley, 1973) referred 24-27\% relative volume of ER in bitch and (Reid and Chandler, 1973; Reid et al., 1976) reported 19.2 to $37.3 \%$. in mice. Hollman (1974) found that ER and mitochondria increased in number from pregnancy to lactation by an average 37.32 and $18.44 \%$, respectively, which was followed by a reduction at involution by an average 38.04 and $22.91 \%$ compared to lactation. We suggest that the relative volume of ER considering its participation in proteosynthetic functional processes of the cell (Hluchý et al.,1995) could positively correlated with the concentration of protein in milk which was

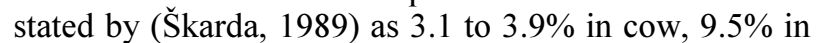
bitch, $10.4 \%$, in rabbits and $11.3 \%$ in rat.

Relative surface can roughly be compared with data of (Uhrín and Kliment, 1982), who found 7.34 to 7.55 $\mathrm{m}^{2} / \mathrm{m}^{3}$ of cytoplasm. Morphology of ER after lactation coincides with the data of other authors. The relative volume of ER in rabbits after lactation is only $1.274 \%$, which is comparable to $1.31 \%$ in cows (Uhrín and
Kliment 1982). Hollman (1974) found that the surface of ER in mouse reaches $4.7 \mu \mathrm{m}^{2} / \mu \mathrm{m}^{3}$. Uhrín and Kliment (1982) found that the surface of ER form 7.34 to $7.55 \mu \mathrm{m}^{2} / \mu \mathrm{m}^{3}$ of cytoplasm of secretory epithelial cells in cows. We have found a fairly level surface $5,630 \mu \mathrm{m}^{2} / \mu \mathrm{m}^{3}$ of cytoplasm. After the end of lactation, we found a decrease of ER relative surface. At the end of lactation would be expected, the regression of the secretory activity and reduced energy needs, the average thickness of cisternae and tubules becomes smaller. Similar results found (Holst et al., 1987). The Golgi apparatus generally was not apparent. Rough endoplasmic reticulum and mitochondria were observed throughout the period studied, although in reduced amounts compared with their presence in lactating tissue. Ultrastructural examination showed that alveolar epithelial cells at d 21 and 30 of involution appear to be functionally active but not secreting milk components.

\section{Conclusion}

Our study shows that the stages of mammogenesis are accompanied by changes in cytoarchitekture of organelle such as endoplasmic reticulum of the mammary epithelial cells. Ultrastructural examination showed that relative volume, average relative surface and average size of endoplasmic reticulum were changed depending to secretory activity. The results showed clear differences between lactation and regression stage. 


\section{Acknowledgement}

We thank the stuff of the Department of Reproduction, Research Institute of Livestock Production in Nitra Slovakia, in particular prof. Vladimír Uhrín for his assitance and Alžbeta Sobčáková for electron microscopy samples processing. We also thank to Dr. Michal Simon from Department of Biochemistry and Genetics, Slovak Academy of Sciences Ivanka pri Dunaji for his support.

\section{Conflict of Interest} interest.

The researches have no any potential conflict of

\section{Funding Information}

This study has been supported by VEGA project No. 2/0006/12 and the VEGA projekt No. 1/0292/14 (Ministry of Education, Slovak Republic).

\section{Author's Contributions}

Svätoslav Hluchý: Conceptualized and supervized the research, made and analyzed elektronograns and drafted the manuscript.

Róbert Toman: Collected samples and calculated all statistics. Both authors read and approved the manuscript.

\section{Ethics}

All experiments and procedures described in this article were undertaken under a project licence approved by Animal Utilization Ethics Commission in accordance with Government Regulation n. 289/2003 and n. $315 / 2003$ of the Laws.

\section{References}

Ghosal, D., N.W. Shappell and T.W. Keenan, 1994. Endoplasmic reticulum lumenal proteins of rat mammary gland. Potential involvement in lipid droplet assembly during lactation. Biochim. Biophys. Acta, 1200: 175-181. PMID: 8031838

Helminen, H.J. and J.L.E. Ericsson, 1968. Studies on mammary gland involution 1: I. On the ultrastructure of the lactating mammary gland. J. Ultrastructure Res., 25: 193-213. DOI: $10.1016 / \mathrm{S} 0022-5320(68) 80069-3$

Holst, B.D., W.L. Hurley and D.R. Nelson, 1987. Involution of the bovine mammary gland: Histological and ultrastructural changes. J. Dairy Sci., 70: 935-944. PMID: 3597934

Hluchý, S., V. Uhrín and P. Čupka, 1995. Histological structure of mammary-glands during lactation in the rabbits. Živočíšná Výroba, 40: 391-397.
Invernizzi, G., A. Naeem and J.J. Loor, 2012. Short communication: Endoplasmic reticulum stress gene network expression in bovine mammary tissue during the lactation cycle. J. Dairy Sci., 95: 2562-2566. DOI: $10.3168 /$ jds.2011-4806

Jimenez, L., C. Rua, E. Muňiz and P. Garcia, 1984. Alveolar epithelial cells of the mammary gland of Lactating Myotis myotis: An Ultrastructural Study. Z. Mikrosk. Anat. Forsch., 98: 465-477. PMID: 6485499

Pulley, L.T., 1973. Ultrastructural and Histochemical demonstration of myoepithelium in the normal canine mammary gland. Am. J. Vet. Res., 34: 1505-1512. PMID: 4128460

Reid, I.M. and R.L. Chandler, 1973. Ultrastructural studies on the bovine mammary gland with particular reference to glycogen distribution. Res. Vet. Sci., 14: 334-340. PMID: 4141786

Reid, I.M., R.D. Harrison and J.C., Anderson, 1976. Experimental staphylococcal mastitis in the mouse. A morphometric study of early changes in mammary gland structure. J. Comp. Pathol., 86: 329-336. PMID: 1270641

Schinko, I., H. Trebbin, E. Fuchs and U. Welsch, 1990. Ultrastructural and histochemical observations on secretory phenomena in the resting human mammary gland. Z. Mikrosk. Anat. Forsch., 104: 578-592. PMID: 2077761

Sordillo, L.M. and S.C. Nickerson, 1988. Morphologic changes in the bovine mammary gland during involution and lactogenesis. Am. J. Vet. Res., 49: 1112-1120. PMID: 3421535

Uhrín, V. and J. Kliment, 1982. Submikroskopická stavba mliečnej žlazy kravy počas laktácie. Živočíšna Výroba, 27: 503-513.

Qu, B., Y. Jiang, F. Zhao, J. Xiao and Q.Z. Li, 2012. Changes of endoplasmic reticulum and mitochondria in mammary epithelial cells during mammogenesis in Chinese Holstein dairy cows. Acta Histochem., 114: 448-53. PMID: 21920588

Mráz, P. and J. Polónyi, 1988. Metódy Elektrónovej Mikroskopie Živočíšnych Tkanív. 1st Edn., Veda, Bratislava, pp: 309.

Hollman, K.H., 1974. Cytology and fine Structure of the Mammary Gland. A Comprehensive Treatise I: Mammary Gland/Development and Maintenance. Larson, B.L. and V.R. Smith (Eds.)., Academic Press, New York, pp: 3-95.

Škarda, J., 1989. Hormonální řízení mamogeneze, laktogeneze a laktace u prežvýkavcú. Živočišna Fyziologie. UFGHZ, VÚŽV Praha. 